\title{
コミュニケーション方法とリテラシー形成（特別発言）
}

\author{
齋藤 佐和
}

\begin{abstract}
要 約：聴覚障害児の学校教育開始後, 約 130 年になる. 20 世紀前半までの職業教育重視の 時代を経て, 現在, 壟学校では通常の学校と同様の教育が目指され大学進学者も増加している. 難聴学級等通常の学校で指導を受けている子どもも多い. 近年コミュニケーション方法は多様 化し, 聴覚口話法を基本としつつ手話を併用する襲学校も増えている. 日本語指導の方法も教 授型からコミュニケーション重視の対話型に変化してきた。聴覚障害児のリテラシーは個人差 が大きく, 平均的には読書力, 作文力とも遅れや偏りが見られる.リテラシー形成には音韻意 識および言語概念への気づきが重要であるが，聴覚障害児は補聴による矯正に加えて，視覚的 情報や筋肉感覚，かな文字などを拠り所にさまざまな感覚を協働させ，時間をかけて特有の音 韻意識に至ると考えられる．音韻意識の定着や日本語による概念の理解を促す指導，さらに小 学校，中学校段階でのリテラシー形成にかかわる息の長い教育的支援が必要である.
\end{abstract}

索引用語：聴覚口話法, 手話併用, 対話型指導法, 音韻意識, リテラシー

\section{Communication Methods and Literacy Acquisition in Children with Hearing Impairments}

\section{Sawa Saito}

\begin{abstract}
About 130 years have passed since education in Japan began for children with hearing impairments. Vocational education was favored through the first half of the 20th century, but today education similar to that at ordinary schools is being conducted at schools for the deaf, and the number of hearing-impaired persons who enter university is increasing. There are also many children who attend classes for the hard of hearing at ordinary schools. Recently, communication methods used at deaf schools have become diversified. Many deaf schools use an aural-oral approach at the base, but schools also using sign language in tandem have increased. Teaching methods for Japanese have also changed from an instructive method to a communication-based method. Individual variations in Japanese literacy achievement in children with hearing impairments are considerable, but on average their achievement in reading and writing is delayed and biased in comparison with hearing children. Literacy acquisition seems to require phonological awareness and understanding of concepts in Japanese. It is thought that children with hearing impairments can acquire, over a long period of time, a specific phonological awareness by simultaneously using various senses including visual information, muscular sense, and Kana-character imagery, in addition to use of hearing aids. Education that
\end{abstract}

目白大学保健医療学部言語聴覚学科：テ339-8501 さいたま市岩梘区浮谷 320

Department of Speech, Language and Hearing Therapy, Faculty of Health Sciences, Mejiro University: 320 Ukiya, Iwatsukiku Saitama-shi, Saitama 339-8501 2006 年 5 月 15 日受理 
develops phonological awareness and understanding of concepts in Japanese is indispensable. Diverse, long-span educational supports related to literacy acquisition must be continued at the elementary and junior high school stages.

Key words: aural-oral method, combined use of sign language, communication-based teaching method, phonological awareness, Japanese literacy

\section{聴覚障害教育の内容と方法の変遷（表 1 )}

1878 年に聴覚障害児の学校教育が京都盲硜院にお いて始まってから 130 年に近い時がたった。学校制度 としては昭和 23 年より 9 年をかけて義務教育化され たが，やがて教育の場は贑学校だけでなく，小・中学 校難聴学級などへと広がっていく. 1960 年代後半から 幼児聴力検查法の開発, 個人用補聴器の飛躍的進歩に 支えられ，今日に続く早期教育，聴覚活用の流れが確 立した，教育の内容も基礎的学習と職業教育の長い時 代を終えて, 現在では通常の学校と対応する教育によ って，高等教育への進学率も上昇し始めている.

聴覚障害教育におけるコミュニケーション手段に も，大きな変化の時期があった。明治期には手話と筆 談で始まり, 日本語の学習は文字を通して始まった。 大正後期に口話法が導入され，読話・発語によるコミ ュニケーションを通して話しことばを獲得させ，その 後に書きことばを学習する健聴児と同様の日本語習得 の道筋が追求されるようになった. 1960 年代後半より 聴覚活用が定着するに伴って, 口話法は保有聴力の活 用と読話を組み合わせた聴覚口話法へと転換してい く.同時に言語音の弁別指標を視覚的に明示するため, 読話に組み合わせてキュードスピーチなどの視覚的サ インが併用されるようになった。さらに 1990 年頃から 手話の社会的認知, また言語としての認知の進展から, コミュニケーションにおける手話併用，あるいは手話 先行の教育方法も主張されるようになった。近年は幼
児期の言語習得期においても龍学校におけるコミュニ ケーション方法は多様化してきている. 幼児期, 児童 期については, 聴覚口話を基本に, 音韻（主として子 音）レベルの指サインーキュードスピーチ，音韻サイ ンなどーや指文字を併用するものと, 聴覚口話・手話・ 指文字を併用するものとに分けられる．手話先行の手 話・日本語のバイリンガル教育を試みる民間団体もあ る。一方, 言語指導法に関しても,「教授型」の方法か ら「対話型」つまりコミュニケーションベースの方法 に変化してきている.

コミュニケーション方法の選択は多様であり, 教育 方法論としての対立意見もあるが, 読み書き能力（リ テラシー）習得の重要性についての認識は共通してい る。聴覚障害児にとってリテラシー獲得は, 自己表現 や学力獲得の基礎としても, 社会的自立の基盤として も，また情報化社会の幅広い知識・情報へのアクセス のためにも大きな意味をもつからである．高いリテラ シーを獲得している事例も決して例外的でなく，個人 差の大きいことは知られているが，一般に読む力，書 く力において困難のある事例が多いことも事実であ る.コミュニケーション手段がどのようなものであれ, リテラシー形成の発達的基盤と発達過程を理解し, そ の形成を助ける息の長い指導論をもつことが必要と考 えられる。

\section{聴覚障害児の読み書き能力に見られる問題}

個人差の大きさは, 聴覚障害児がリテラシー形成に

表 1 聴覚障害教育の内容と方法の変遷

\footnotetext{
- 明治期〜大正期

文字による日本語学習, 基本的な学習, 職業教育 手話と筆談

- 大正末期〜昭和 30 年代

話し言葉と文字による日本語学習, 中等教育, 職業教育

口話法 (読話・発語) の普及，「教授型」の言語指導

・昭和 40 年代

早期発見と聴覚活用に基づく早期教育 ( 3 歳〜, 現在は 0 歳 ), 難聴教育, 高等教 育開始,「対応の教育」の実現

聴覚活用の定着, 視覚的コミュニケーション手段の併用, 手話の社会的認知の進展, 教育の場での手話使用の増加, 「対話型」の言語指導法
} 


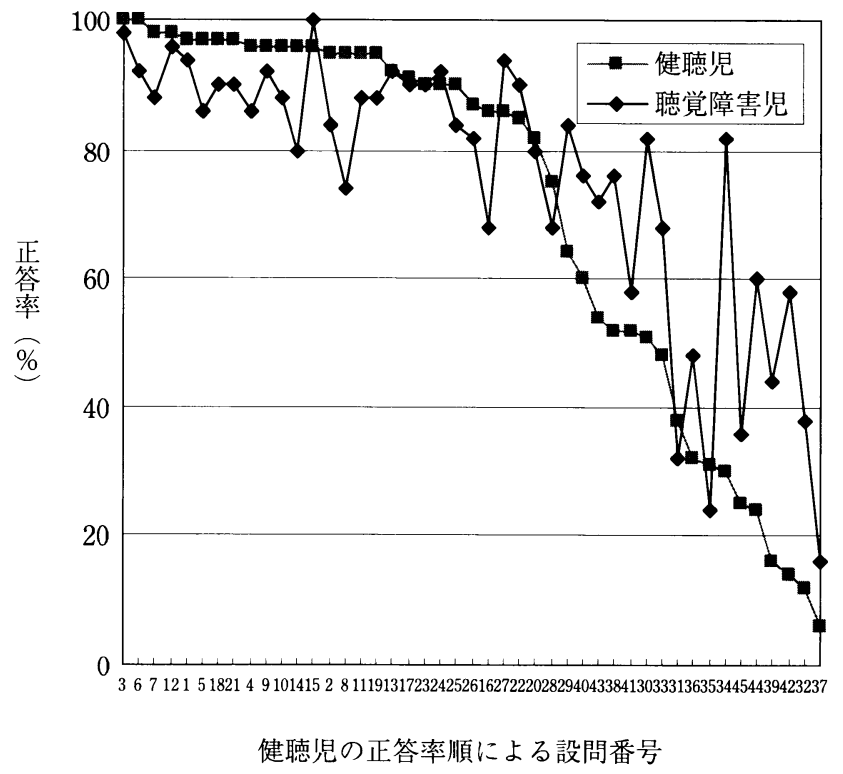

読字力における健聴児の正答率との関連性

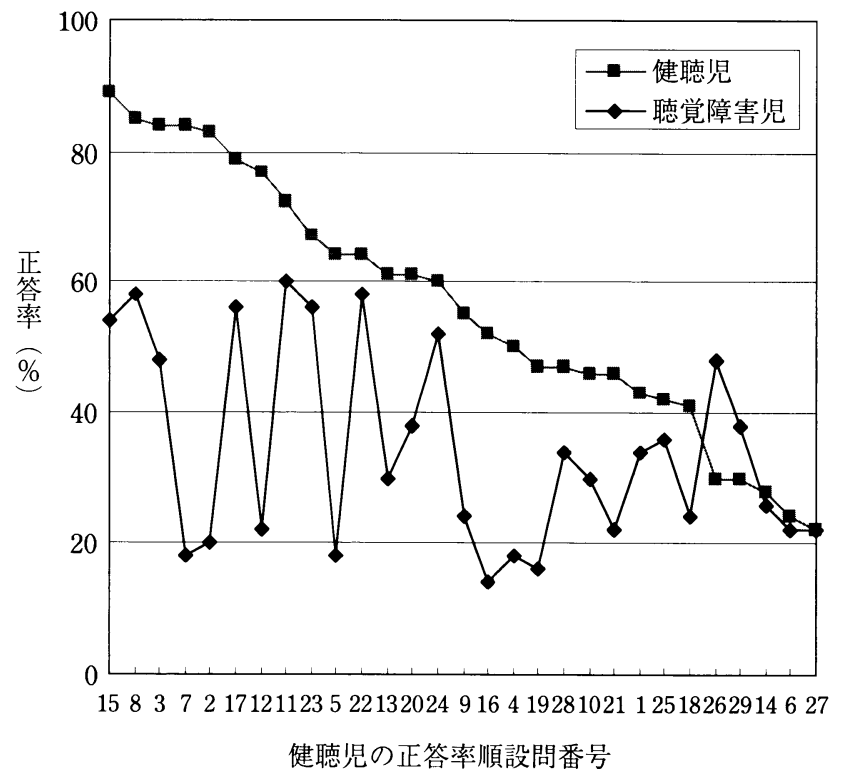

語彙力における健聴児の正答率との関連性

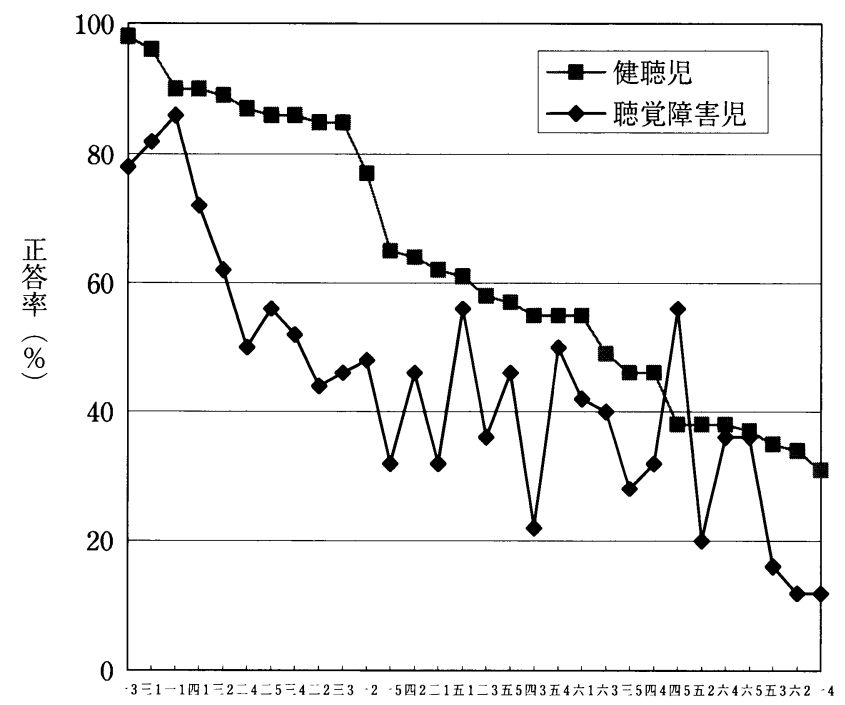

健聴児の正答率順設問番号

読解・鑑賞力における健常児の正答率との関連性

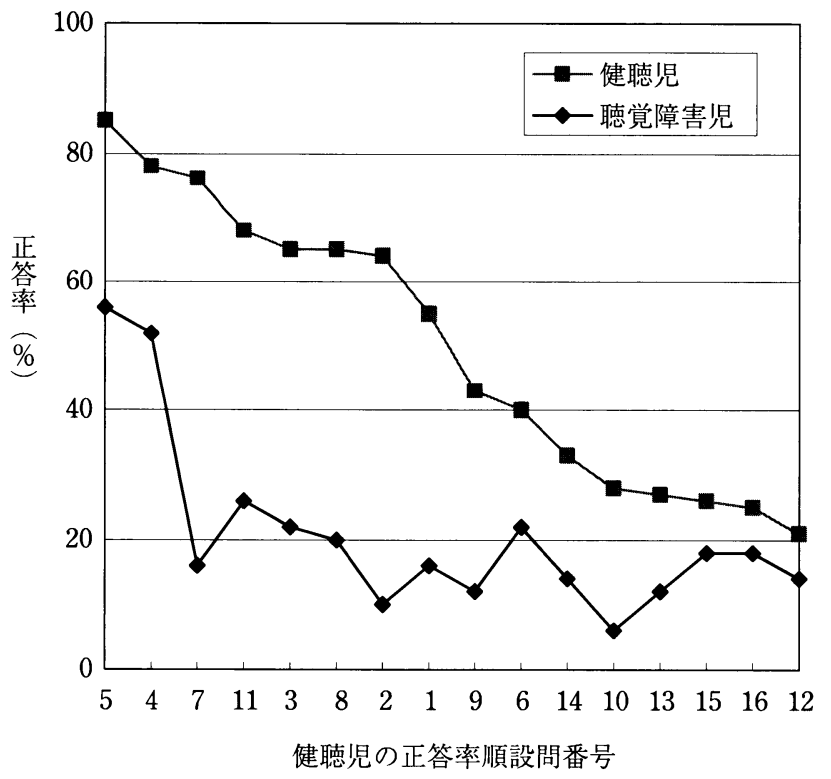

文法力における健聴児の正答率との関連性

図 1 聴覚障害児の読書力（田中耕司，2002 ${ }^{2}$ より転載）

おいて潜在的可能性が大きいことを示すものである が，一般的には読書力診断検査などの総点の伸びが小 学校中学年で鈍化してくることが報告されている11. 図 1 に, 公立襲学校小学部 5 年から中学部 3 年生の読 書力下位検査問題別正答率を標準化デー夕と比較した ものを著者の同意を得て転載したが2), この結果は聴 覚障害児の読書力の構造的特徵をよく示している.

健聴児の問題別正答率の傾向と比べて, 読字力にお いては優れており, 読解力における遅れも量的なもの といえる, 一方, 語彙力, 文法力においては量的な遅
れより質的な差異が指摘でき，誤答分析による的確な 問題点解明が必要になる。

書く力については,読解力と同様に個人差は大きい. 一般の作文コンクールでの上位入賞例も増加している 一方，過去において指摘された問題3はまだ解決され ているとはいえない. 文表現のパターン化，時系列的 な文章構成が多いなど一般的な文章構成力の不足, 構 文上の問題 (助詞, 助動詞の使用上の問題, 主述の呼 応の問題など), 使用語彙の少なさや用法上の問題, 表 記上の問題などであるが，これらは日本語の書きこと 
ばを自分のことばとして十分駆使できるにいたってい ない状態を反映するものである．聴覚障害児の苦手な 部分として, 評価に基づく適切な教育的対応が必要で ある。

\section{リテラシー形成のための発達的基盤}

リテラシー形成には長い年月を要するが，その出発 点となるかな文字学習のためには以下のような発達的 基盤が必要である.

1. 字形の識別力（ひらかな文字の識別）

2. 音韻意識の発達（日本語音節への気づき） 一単語の音節分解・認知能力 (Phonological Awareness)

一単語の音系列の保持・記銘・再生能力 (Phonological Coding)

3. 幼児後期の言語能力 (ことばの意味への気づき) 一ことばの文脈による理解・表現

ーことばの意味についての質問，説明の始まり 一般に字形の識別力に関しては聴覚障害児には特に 困難はない. 問題は, 補聴によっても音声言語の聴覚 的認知が非常に限られている状態で音韻意識の発達が 可能かという点である. 日本の幼児の単語の音節分 解・認知能力についての天野の実験研究4) 聴覚障害 幼児に追試して, 筆者 ${ }^{5}$ は, 時間は要しても聴覚障害児 の場合も音韻意識の形成は可能であることを明らかに した．聴覚的には識別できない音韻の違いを，発音指 導を通して視覚的あるいは筋肉知覚的に体得したり, 指文字やキュードスピーチなどの使用によって識別す るようになったり, 文字自体が意識化を促進したりす るなど,子どもによって拠り所となる指標は異なるが, さまざまな感覚を協働させて聴覚障害児特有の音韻意 識に至るのではないかと考えられる. 聴覚的に形成さ れる音韻表象とは異なる組成であるが, 統合化された 表象レベルでの音韻意識とみなすことができよう.

リテラシー形成のための他の重要な発達基盤は, こ とばの文脈での理解・表現が可能になるような言語能 力の発達である. 生活経験にまつわって日本語を使う 経験を累積していくことによって, 子どもは状況の文 脈に依存しない, ことばによる伝達や想像が可能にな ってくる．健聴児より多くの時間を要し，きめの細か い対話活動が必要になるが, ことばの文脈による伝達 が円滑になり，ことばの意味をことばで理解する方略
が身に付き始めることが，音韻意識の形成と並んでリ テラシー形成の重要な基盤である ${ }^{6)}$.

\section{聴覚障害児のリテラシー形成のために}

長年の経験から, 襲学校, 難聴学級などでは次の 1 〜 3 のような段階を踏んで, リテラシー形成に向けた 指導を実践している。日本語習得に抢ける困難が大き い場合は，1 1 2 の指導の比重が多く長く続くことに なるが，リテラシー形成のためには，その段階にとど まらず, 国語科としての指導を積み上げる必要がある.

1. 入門期の指導: 文字と音節, 語, 文の対応の学 習, 文字が意味を伝えることの学習, 書くことの始ま り（単語，口頭作文の文字化）

2. 言語指導としての読み書き指導：個人差に応じ た読み書き指導（生活言語を中心とした読み教材の工 夫と日記などの活用）

3. 国語科としての読み書き指導: 読解の指導 (事 実, 様子, 気持, 筋道, 要点), 語彙拡充のための指導, 読書指導, 作文指導

特別な方法があるわけではない. 聴覚障害児が読み 書きに親しみ，より豊かな日本語を自力で獲得するよ うになるまで, 発達段階に応じた息の長いきめ細かな 教育を継続していくことこそ，リテラシー形成のため の王道といえる.

\section{文献}

1）我妻敏博：聴覚障害児の “読み” の能力. 国立特殊教育総 合研究所特別研究報告一手指法等の評価と適応に関する研 究, 61-66 頁, 1983 .

2) 田中耕司：聴覚障害児の読書力と文章力に関連する諸能力 に関する基礎的研究. 平成 13 年度東京学芸大学修士論文 (未公刊), 2002.

3）井原栄二, 草薙進郎, 都築繁幸：聴覚障害児の語い, 読み, 作文指導, 明治図書, 1982 .

4）天野 清：語の音韻構造の分析行為の形成とかな文字の読 みの学習. 教育心理学研究, 18(2):12-29, 1970.

5）斎藤佐和：聴覚障害児における単語の音節分解㧍よび抽出 に関する研究. 東京教育大学教育学部紀要, $24: 205-213$, 1978.

6) 斎藤佐和：言語の発達。聴覚障害の心理, 田研出版, 1999.

別刷請求先：テ339-8501さいたま市岩梘区浮谷 320

目白大学保健医療学部言語聴覚学科

齋藤佐和 